\title{
Provisions Of Labour Law To Safeguard The Interest Of Female Workers To Ensure Equality In India
}

\author{
Sony Kulshrestha
}

\begin{abstract}
The jurisprudence of economic development has demonstrated the vigorous role of industrial laws as an instrument of societal and economic justice. Social justice means the attainment of socio-economic objectives laid down by the legislature. Financial soundness is the base of principle of equality of female workers. For a long time, female workers were discriminated in matters of employment and it was felt that gender equality did not find its fulfilment even at the hands of judges. If, we really want to upgrade the status of female workers we have to apportion major significant roles to them. Female are biologically different from males so here equality denotes the equal role considering this condition but difference in term of wages is discrimination. The problem was taken care of by enacting numerous profemale worker provisions like the Maternity Benefit Act, 1961 with the Amendment Act of 2017 and the Equal Remuneration Act, 1976 etc. The Constitution of India also directed the State to make special provisions in favour of them. The Supreme Court by interpreting of articles fourteen, fifteen sixteen and twenty-one of the Indian Constitution has intended significantly to ensure gender justice and no discrimination policy in employment matters. With the above introduction the researcher in this research paper wants to highlight the provisions of Labour Laws related to female workers and how it is ensuring and sustaining the socio- economic justice and equality to maintain the dignity and raise the standard in our society. To justify its observation; the researcher has gone through the various statutory enactments, reviews, the report of various social welfare agencies and the interpretation done by judiciary in number of cases.
\end{abstract}

Keywords: Employment, Enactments, Industrialization, Inequality, Socio-economic, Sustain.

\section{INTRODUCTION}

In the sphere of Labour Law, the female workers have been assigned a special position in view of their unique characteristics mentally and physically.

The law of the land ie. The Constitution of India contains number of provisions to prohibit gender based discrimination and interest of the woman. The preamble specifically declares that main purposes of the constitution is to secure justice whether it is economic, social or political and also the opportunity and status equality to all the citizens. This is irrespective of the sex. This specific mandate given to the

Revised Manuscript Received on July 05, 2019.

Dr. Sony Kulshrestha Associate Professor, School of Law, Manipal University Jaipur
State has resulted in number of protective, beneficial and health provisions made in various enactments for the benefit of woman.

Recently in the case of Anshu Rani v. State of UP (2019) the Allahabad High Court held that a woman employee is entitled to maternity leave for a full period of six months.

The Supreme court in Associate Banks Officers Association v. State Bank of India ${ }^{1}$ explained of the principle "equal pay for equal work" meaning by no discrimination should be there between male and female worker with respect to the wages of their equal work in the same organisation. In India, the equal remuneration to male and female workers and is meant to prevent discrimination on the ground of sex, against female workers in the matter of employment.

In labour law there are number of provisions which are enacted and incorporated for the benefit of female workers, such as:

a. Equal Remuneration for Men and Female workers

b. Maternity Benefit

c. Employees' State Insurance

d. Factory Employment

e. Mines Employment

f. Sexual Harassment of Female workers at Workplace

a. Equal Remuneration for Men and Female workers

i. The Equal Remuneration Act, 1976: The Constitution of India in its Article 39 of directive principles of state policy explicitly directs the States to make provisions to ensure equal pay for equal work for both male and female workers. For the said purpose, Equal Remuneration Act, 1976 has been enacted.

ii. Object: To maintain the equality between male and female worker by paying them equal pay for equal work of a similar nature. ${ }^{2}$

iii. Equal Work: To decide the concept of equal work there are number of factors like skills, nature and condition of work. These factors should be taken care of before rationally distributing

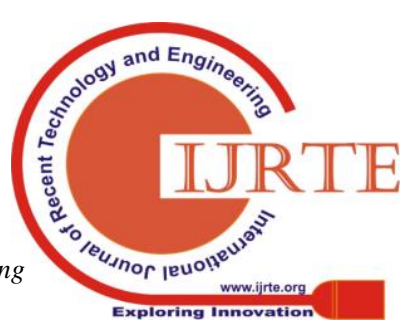


the responsibility and to avoid discrimination. ${ }^{3}$ In doing so the duties actually and generally performed by men and female workers and not theoretically possible, should be looked at.

In Air- India v. Nergesh Meerza ${ }^{4}$, there was the question of unequal post-retirement benefits between the air hostesses and assistant flight members though their work is more or similar. The Supreme Court held that:

"If at the threshold the basic requirements of two classes are absolutely different and poles apart even though both the classes may during the flight work as cabin crew, they would not become one class of service."

The ground of difference was based upon the requirement and conditions of service not upon or based on the sex. So this was not the case of discrimination.

iv. Penalties: The punishment under this provision for committing any act by employer which is listed below is minimum ten thousand rupees fine which may increase to twenty thousand or imprisonment of three months to one year or both for first offence. For the second or subsequent offence the employer may be imprisoned up to two years.

The acts which are in contravention of this Act:

(a) Making any recruitment.

(b) Making any unequal payment of remuneration for similar nature work to male and female workers.

(c) Making any discrimination between men and female workers. or

(d) Under s.6 of the Act, if employer is omitting or failing to carry out any directions made by the Appropriate Government.

\section{b. Maternity Benefit}

i. The Maternity Benefit Act, 1961 and The Maternity Benefit (Amendment) Act, 2017: The parliament has passed the Maternity Benefit Act in the year 1961 in pursuance of the constitutional provision under Article Forty-two which guides the State to inculcate the norms for ensuring fair and humanitarian environment of work and for maternity aid/relief/benefit.

ii. Object: Female are biologically different from male because they are blessed with their child birth capability. During this period, they need special care but with no economic loss that's why the parliament enacted this Act to provide maternity and other benefits during certain period (Before and after child birth).

iii. Maternity Benefit: It denotes the monetary benefits which can be calculated as the average of her daily wage during the time of actual absence what she is entitled to claim for as per the provisions of the Act. The maximum period for maternity benefit is 26 weeks of which maximum 8 weeks shall be afore the date of her anticipated delivery. ${ }^{5}$

In a landmark judgment in the case Municipal Corporation of Delhi v. Female Workers (Muster Roll) ${ }^{6}$ the Supreme Court declares that both regular female employees and those engaged on casual base or those who are on daily wage base on muster roll are entitled to the maternity assistance under the Maternity Benefit Act, 1961 and Amendment Act of 2017.

iv. Other Benefits: Leave for medical termination of pregnancy or miscarriage, payment of medical bonus, leave with wages for tubectomy operation, leave for illness due to pregnancy, delivery etc., nursing breaks and no discrimination during absence of pregnancy.

v. Penalties: If any organization/ employer fails to pay any amount (legally acquired by her) of maternity benefit to a woman under this Act, the punishment for the act is minimum 3 months to maximum one year and fine also. If an employer obstructs the Inspector or any other authority appointed by the government under this Act from implementing the provision of this Act, the same is an offence and is punishable. Thus this Act creates special offences in so far as non-implementation of the provision of this Act is concerned.

c. Employees' State Insurance

The Employees' State Insurance Act, 1948: In case of illness, maternity, physical disablement whether temporary or permanent; the workers are worried about their source of income, the Employees' State Insurance Act, 1948 provides them a security of income in case of any contingency by protecting their interests. The Act also guarantees reasonably good medical care to workers and their immediate dependants. Following the promulgation of the Employees' State Insurance Act the Central Govt. set up the Employees' State Insurance Corporation to administer the Scheme. On February $24^{\text {th }}$ 1952 this scheme was implemented at Deldi and Kanpur. The benefit provided to the employees under the Act are also in conformity with International Labour Organization conventions.

\section{d. Factory Employment}

The Factories Act, 1948: S. 27 of the Act, "no woman or child shall be employed for pressing cotton in any part of a factory in which a cotton opener is at work." The reason for such a provision appears to be safeguard the life and limbs of the woman and child employed. S. 48 of the Factories Act states that in each factory where exceeding the number of thirty female workers are usually employed, for their children those who are below six years of the age, comfortable rooms/ space should be given to daily care of 
those children. The appointment of a well-trained woman is the duty of employer to take care of the infants and children of those working females in that factory. To maintain the hygiene, is the prima facie duty of the employer. Thus S. 48 imposes a statutory compulsion on the employers to afford the crèche facility for the children of female workers. U/s 19(1) there is a provision of providing to workers in entire factory working hours "prescribed type sufficient latrine and urinal accommodation.

\section{e. Mines Employment}

The Mines Act, 1952: Female workers are not allowed to do work beyond the duration ie. between 6 am and $7 \mathrm{pm}$ in a mine which is below the ground. ${ }^{7}$ Again the section says that if a woman is employed above the ground in a mine even though there is restriction on her working hours ie. There should be an interval of 11 hours between the termination of one-day employment and starting of second day employment. This is to enabling the woman employee to avail sufficient rest between two successive working days.

\section{f. Sexual Harassment of Female workers at Workplace}

The Sexual Harassment of Female workers at Workplace (Prevention, Prohibition and Redressal) Act, 2013: Equality includes the equal work environment safe for male and female workers both. Any kind of harassment is strictly prohibited whether mental or physical or sexual. To safeguard the interest of female workers at work place parliament has enacted this Act. Article 14,15 and 21 of The Indian Constitution gives us the right to quality and right to life and personal liberty as fundamental rights, sexual harassment at workplace violates these rights. It creates an insecure and unhealthy work environment for female workers with loads of stress, uncertainty and depression which is affecting the health of female worker and adversely affects her overall growth.

As per the Vishaka judgment ${ }^{8}$, 'Sexual Harassment' is a vast terminology which includes almost every form of unwelcomed act such as physical touch, any demand for sexual favour, sexually oriented remarks, demonstration of any porn video or clip or audio or any other unwelcomed direct or implied conduct.

Punishment: If an employee is indulging in any aforesaid act which comes under the definition of sexual harassment, he shall be punished with the punishment mentioned in the Act. Section 13 of the Act lists various provisions which are as follows:

i. any punishment mentioned in the organizational service rules;

ii. if there are no service rules then the employer can take any disciplinary action against the employee such as: asking for written apology by giving him warning,

iii. stopping the promotion, if there are no such service rules then the organisation can ask for any disciplinary action including written apology, warning, reprimand, condemnation, withholding of any or every monetary benefit including salary hike or termination of his services. The employer may also suggest him for counselling sessions; and

iv. the employer can compensate the compensation given to the female employee who is aggrieved from his wages.

\section{CONCLUSION}

Equality composes the basic structure of Indian Constitution. For the protection of those the parliament and state legislatures are empowered to make laws and ensure their enforcement. The legislature has enacted ample of laws specially under labour laws to secure financial equality of man and women by providing special benefits to the female workers. Beside these special benefits the female workers also enjoy common benefits which are available to both the male as well as female employees working in same industries. They include abolition of bonded labour system, prohibition of child labour, insurance of workers, provident fund, gratuity, weekly holidays, canteen facilities, rest rooms and medical benefits etc. This list only illustrative in nature and exhaustive. Their natural disadvantages and unique features of motherhood, justifies the requirement of special labour law provisions and the Indian Constitution which provides in its Article 15 (3) that the State may make special provisions for the woman and children. All the above provisions have been made in pursuance of the power conferred on the State by virtue of the above fundamental rights.

\section{REFERENCES}

Books/Articles:

1. Mamta Rao, Law relating to Female workers and Children, $4^{\text {th }}$ Edition, Lucknow: Eastern Book Company, 2018.

2. G. B. Reddy, Female workers and the Law, $9^{\text {th }}$ Edition rep., Hyderabad: Gogia Law Agency, 2018.

3. R. Hunter, "Representing Gender in Legal Analysis: A Case/Book Study" (1991) 18 Melbourne University Law Review 305, 305.

4. C. K. Johri, Labour law in India, KNS1220 J71, Kluwer Law International, 2012.

5. S. Routh, Enhancing Capabilities through Labour Law: Informal Workers in India, New York, Routledge, 2014.

6. P. L. Malik, Labour Law (Covering Labour Law in India, 2 Volumes, Eastern Book Company, 2015. pp. 1-3656.

\section{Reports:}

7. Reports: Government of India Planning Commission, Report of the Working Group on Labour Laws and other Labour Regulations, 2007.

Journals:
Published By: Blue Eyes Intelligence Engineering \& Sciences Publication 
8. Journals: "Supreme Court Cases (Labour \& Services)". SCC(L\&S). Lucknow: EBC, 2015. (Monthly).

Supreme Court of India Digest containing Case Law Labour \& Services:

9. Surendra Malik. Supreme Court Labour \& Services Digest (Hardcover). India: EBC.

\section{Webliography:}

10. https://labour.gov.in/womenlabour/about-women-labour

11. https://blog.ipleaders.in/womens-rights-labour-law-statute s-india/

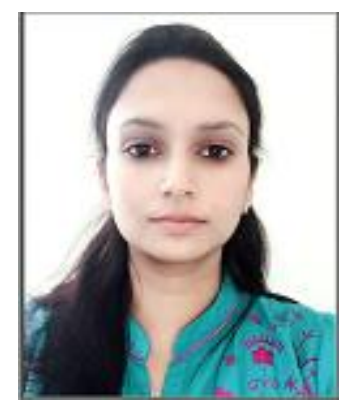

Dr Sony Kulshrestha is an Associate Professor in the School of Law, Manipal University Jaipur. She qualified NET (JRF) conducted by UGC in the year 2008. Dr Kulshrestha obtained her $\mathrm{PhD}$ in Law from the University of Rajasthan in 2012.

She is a corporate law expert with over ten years of teaching and administrative experience. She has successfully coordinated seven National Moot Court Competitions. She has been instrumental in organizing Legal Awareness Camps in the surrounding villages. In her present role, she assists the School of Law in developing alliances with institutes, academicians, professionals and corporates and contributes to academics and research. She has published 14 research papers in peer reviewed journals and 4 book chapters. Currently she is guiding 06 research scholars from which two have presented their pre-synopsis.

Prior to joining MUJ, she was associated with the University Five Year Law College (University of Rajasthan) for over five years and had successfully handled multiple and diverse responsibilities. 